\title{
SOIL ORGANIC MATTER AND FERTILITY OF ANTHROPOGENIC DARK EARTHS (TERRA PRETA DE ÍNDIO) IN THE BRAZILIAN AMAZON BASIN ${ }^{(1)}$
}

\author{
Tony Jarbas Ferreira Cunha ${ }^{(2)}$, Beata Emoke Madari ${ }^{(3)}$, Luciano \\ Pasqualoto Canellas ${ }^{(4)}$, Lucedino Paixão Ribeiro ${ }^{(5)}$, Vinicius \\ de Melo Benites ${ }^{(6)} \&$ Gabriel de Araújo Santos ${ }^{(7)}$
}

\begin{abstract}
SUMMARY
Fertility properties, total C (Ctot), and chemical soil organic matter fractions (fulvic acid fraction - FA, humic acid fraction - HA, humin fraction - H) of anthropogenic dark earths (Terra Preta de Índio) of the Amazon basin were compared with those of Ferralsols with no anthropogenic A horizon. Terra Preta soils had a higher fertility (pH: 5.1-5.4; Sum of bases, SB: $8.93-10.33 \mathrm{cmol}_{\mathrm{c}} \mathrm{kg}^{-1}$, CEC: 17.2-17.5 cmol $_{\mathrm{c}} \mathrm{kg}^{-1}, \mathrm{~V}: 51-59 \%$, P: 116-291 $\left.\mathrm{mg} \mathrm{kg}^{-1}\right)$ and Ctot (44.6-44.7 $\left.\mathrm{g} \mathrm{kg}^{-1}\right)$ than adjacent Ferralsols (pH: 4.4; SB: $2.04 \mathrm{cmol}_{\mathrm{c}} \mathrm{kg}^{-1}$, CEC: $9.5 \mathrm{cmol}_{\mathrm{c}} \mathrm{kg}^{-1}$, V: 21 \%, P $5 \mathrm{mg} \mathrm{kg}^{-1}, \mathrm{C}: 37.9 \mathrm{~g} \mathrm{~kg}^{-1}$ ). The $\mathrm{C}$ distribution among humic substance fractions (FA, HA, H) in Terra Preta soils was also different, as shown by the ratios HA:FA and EA/ $\mathrm{H}$ (EA=HA+FA) (2.1-3.0 and 1.06-1.08 for Terra Preta and 1.2 and 0.72 for Ferralsols, respectively). While the cation exchange capacity (CEC), of Ferralsols correlated with FA $(r=0.97)$, the CEC of Terra Preta correlated with $\mathrm{H}(\mathrm{r}=0.82)$. The correlation of the fertility of Terra Preta with the highly stable soil organic matter fraction (H) is highly significant for the development of sustainable soil fertility management models in tropical ecosystems.
\end{abstract}

Index terms: humic substances, humin fraction, cation exchange capacity, total soil carbon.

\footnotetext{
(1) Recebido para publicação em novembro de 2007 e aprovado em janeiro de 2009.

(2) Embrapa Semi-Árido, Br 428, km 152, P.O. Box 23, CEP 56302-970 Petrolina (PE). E-mail: tony@cpatsa.embrapa.br

${ }^{(3)}$ Embrapa Arroz e Feijão, Rodovia GO-462, Km 12, Fazenda Capivara, Zona Rural. Caixa Postal 179, CEP 75375-000, Santo Antonio de Goiás (GO). E-mail: madari@cnpaf.embrapa.br

(4) Universidade do Norte Fluminense. Av. Alberto Lamego 2000, CEP 28013-600 Campos dos Goytacazes (RJ). E-mail: canellas@uenf.br

(5) Universidade Federal da Bahia. Rua Barão de Geremoabo, s/n, Campus Universitário de Ondina, CEP 40170-150 Salvador (BA) E-mail: lucedino@ufba.br

(6) Embrapa Solos. Rua Jardim Botânico 1.024, Jardim Botânico, CEP 22460-000 Rio de Janeiro (RJ). E-mail: vinicius@cnps.embrapa.br

(7) Universidade Federal Rural do Rio de Janeiro. BR 465, Km 7, CEP 23890-000 Seropédica (RJ). E-mail:gasantos@ufrrj.br
} 


\title{
RESUMO: MATÉRIA ORGÂNICA E FERTILIDADE DE SOLOS ANTROPOGÊEICOS (TERRA PRETA DE ÍNDIO) DA BACIA AMAZÔNICA BRASILEIRA
}

\begin{abstract}
Propriedades de fertilidade, carbono total (Ctot) e frações químicas da matéria orgânica (fração ácidos fúlvicos - FA, fração ácidos húmicos - HA e fração humina-HUM) foram comparados entre solos antrópicos (Terra Preta de Índio) e Latossolos sem horizonte A antrópico. Os solos antrópicos apresentaram maior fertilidade ( $\mathrm{HH}$ : 5,1-5,4; S: 8,9310,33 $\mathrm{cmol}_{c} \mathrm{~kg}^{-1}$; CEC: 17,2-17,5 $\mathrm{cmol}_{c} \mathrm{~kg}^{-1}$; $\mathrm{V}: 51-59 \%$; $: 116$-291 $\mathrm{mg} \mathrm{kg}^{-1}$ ) e maiores teores de carbono total (44,6-44,7 $\mathrm{g} \mathrm{kg}^{-1}$ ) que os Latossolos (pH: 4,4; S: 2,04 $\mathrm{cmol}_{\mathrm{c}} \mathrm{kg}^{-1}$; CEC: 9,5 $\mathrm{cmol}_{\mathrm{c}} \mathrm{kg}^{-1}$; $\mathrm{V}: 21 \%, P: 5 \mathrm{mg} \mathrm{kg}^{-1}$, Ctot: $\left.37,9 \mathrm{~g} \mathrm{~kg}^{-1}\right)$. Os solos antrópicos também tiveram distribuição diferenciada de C entre as frações das substâncias húmicas (FA, HÁ e HUM), expressa pelas razões HA:FA e EA:HUM (EA = HA + FA), que foram de 2,1-3,0 e 1,06-1,08 para as Terras Pretas de Índio e de 1,2 e 0,72 para Latossolos, respectivamente. Enquanto a capacidade de troca catiônica (CTC) de Latossolos apresentou correlação com a fração $F A$ ( $r=$ 0,97), a CTC das Terras Pretas de Indio correlacionou-se com a fração HUM $(r=0,82)$. Essa correlação entre a fertilidade das Terras Pretas de Índio e a fração mais estável das substâncias húmicas (HUM) tem importantes implicações no desenvolvimento de modelos sustentáveis de manejo da fertilidade de solos em ecossistemas tropicais.
\end{abstract}

Termos de indexação: substâncias húmicas, fração humina, capacidade de troca catiônica, carbono total do solo.

\section{INTRODUCTION}

The role of organic matter (SOM) in soil fertility has long been known. The relationship between dark soils and the use of organic wastes and agricultural production were observed for thousands of years (Vaughan \& Malcolm, 1985). Recently, the study of the humified fraction of soil organic matter (SOM), the humic substances (HS), has received new interest in view of its extremely important role in environmental protection (Hargitai, 1993). The disequilibrium caused by the removal of natural vegetation has led to a degradation of the edaphic environment and diminished the capacity to sustain life in the long term (Mielniczuk et al., 2003). In humid and hot tropical environments, soils, due to the pronounced weathering process resulting in an intense removal of silica and bases by lixiviation, are acid, and consequently, have low natural fertility (Soares et al., 2005). This restriction, however, does not reduce the biodiversity and development of exuberant vegetation as in the case of the Amazon Forest. Litter deposition on the soil surface is high (8-10 Mg ha-1 $\left.\mathrm{yr}^{-1}\right)$ and the flux and turnover of nutrients intensive (Villela \& Proctor, 1999). If these dynamics are disturbed, the soil ecosystem becomes vulnerable. The SOM therefore plays an important role in environmental protection.

In the highly weathered soils of Amazonia the predominant clay minerals are 1:1 type silicate clays such as kaolinite, and $\mathrm{Fe}$ and $\mathrm{Al}$ oxides, hydroxides, and oxihidroxides, which have little or no structural charge. Cation exchange capacity, complex formation, aggregation of soil particles and gas exchange therefore depend on the development of surface charges (Sposito, 1989). This process is $\mathrm{pH}$-dependent (Fontes et al., 2001) and the charge density of the above-cited mineral types are low, even under acidic conditions. The $\mathrm{pH}$ dependent charge density of these minerals rarely exceeds $5 \mathrm{cmol}_{\mathrm{c}} \mathrm{kg}^{-1}$ soil (Soares et al., 2005). In these soils the humified organic matter (HS) is the most important factor for negative charge development by the dissociation of $\mathrm{H}^{+}$from their oxygenated functional groups (Peixoto, 1997). Humic substances comprise a mixture of colloidal molecules without discrete and defined chemical structure with variable $\mathrm{C}, \mathrm{N}, \mathrm{H}, \mathrm{N}$, $\mathrm{O}$, and $\mathrm{S}$ contents and varying size and shape, according to environmental conditions (Sposito, 1989). In laboratory conditions, HS can be separated based on solubility properties. Although, as mentioned before, the HS can not be separated into chemically well-defined fractions, the separation of these operationally defined fractions can be useful for comparative purposes. The fulvic acid fraction (FA) is a soluble fraction in both alkaline and acidic dilute aqueous medium; the humic acid fraction (HA) is coagulated when the dilute alkaline solution is acidified at $\mathrm{pH}<2$, and the humin fraction $(\mathrm{H})$ is the residual fraction after the alkaline soil extract. Chemical and electrochemical properties of each one of these humic fractions are different.

Soils without chemical restriction and therefore with more biological activity have more HA (Orlov, 1985). In temperate climate environment, the HA content in soils with high negative charge density is high and the HA:FA ratio usually higher than 1.0 
(Kononova, 1966). In highly weathered tropical soils, the predominant fraction of $\mathrm{HS}$ is humin $(\mathrm{H})$ (Yagi et al., 2003). In general, the low content of exchangeable bases in highly weathered soils reduces the intensity of the humification processes (condensation and synthesis) (Canellas et al., 2002). As a consequence, the ratio HA:FA is lower. Soil management practices greatly affect quantity, composition, and proportions of the humic substances. As the fertility of highly weathered soils largely depends on the quantity and quality of SOM, it is highly probable that the changes caused by management practices in HS fractions influence soil fertility considerably. Based on studies of highly weathered soils under different soil management systems (Canellas et al., 2003; Souza \& Melo, 2003; Yagi et al., 2003) a relationship between HA content and soil fertility was indicated. Therefore, the use of HA or the ratio HA:FA as soil quality indicator may be a useful tool for the evaluation of tropical soil management systems.

The anthropogenic dark earths (Terra Preta de Indio or Indian Black Earth) are soils that can be distinguished from other soils by particular characteristics that are the products of ancient anthropic activities. Kämpf et al. (2003), in a tentative to ease the identification and description of anthropogenic dark earths, suggested for these soils the Archaeo-pedological Classification key, with associated nomenclature, using the Brazilian Soil Classification System (Embrapa, 2006), and some other classification systems (e.g. US Soil Taxonomy, WRB) as bases. According thereto, the anthropogenic dark earths of Amazonia would belong to the group of Archaeo-anthrosols together with other ancient anthrosols. The key to identify this group would be a diagnostic of the horizon called archaeoanthropedogenic, a surface or subsurface horizon, developed under the influence of long-standing ancient human activities. In the Amazon basin, their formation, most frequently, is attributed to ancient agricultural activity (Woods \& McCann, 2001) by former Amazon civilizations. Characteristic properties of these soils are the presence of artifacts (e.g. ceramics, lithics, etc.) at any amount, and/or Mehlich-1 extractable $\mathrm{P}$ in the fine earth fraction of at least $65 \mathrm{mg} \mathrm{kg}^{-1}$, charcoal in the fine earth fraction, organic C content determined by the Walkley-Black method (Embrapa, 1997) of $10 \mathrm{~g} \mathrm{~kg}^{-1}$ or more in the fine earth. In the absence of any other evidence of ancient anthropic activity, HA:FA ratio must be $\geq 2.0$. Both the organic $\mathrm{C}$ content and the HA:FA ratio should be higher from the soil surface down to a depth of $0.6 \mathrm{~m}$ or more in comparison to surrounding background soils. Indicators of anthropic origin can further be the presence of fragments of shells and other aquatic organisms, bone artifacts, or accumulation of earthy compost or mud, or solid earth additions with or without cultural artifacts. Clear spatial association of soil with prior human activities can also be an indicator of Archaeo-anthropogenic soils. Such soils were formed on a wide array of soil classes that can be characterized by the $4^{\text {th }}$ level units of the proposed Archaeo-pedological Classification.

Today these soils represent important islands of high soil fertility in the Amazon environment. The exact management practices responsible for the formation of anthropogenic dark earths still remain unclear but the relation between SOM and their production potential became evident (Cunha, 2005).

The objective of this study was to compare the $\mathrm{C}$ distribution among the humic substances fractions in highly weathered soils in the Amazon basin with and without archaeo-anthropedogenic horizon, and to evaluate the relation between the humified fraction of SOM and the chemical and fertility properties in these soils through investigating soil samples originating from widely distributed sampling sites in the Eastern half of Amazonas state.

\section{MATERIAL AND METHODS}

\section{Site description and soil samples}

Twenty two soil samples were collected in eight areas of the State of Amazonas, Brazil: Humaitá, Apuí, Novo Aripuanã, Manicoré, Rio Preto da Eva, Iranduba, Novo Airão and Açutuba (Figure 1).

The soils were formed on Tertiary sediment and quartz-feldspar gneisses (Sombroek, 1966). Eighteen of the examined 22 soils were Ferralsols (FAO, 1994) presenting anthropogenic A horizon (or archaeoanthropedogenic horizon) (Latossolo Amarelo distrófico antrópico by the Brazilian Soil Classification System - SiBCS; Embrapa, 2006) and four soils were Ferralsols without anthropogenic A horizon (Latossolo Amarelo distrófico típico by SiBCS). The sampling sites represented areas under agricultural cultivation and under native forest (Table 1). The sites where the soils did not have antropogenic A horizon were native forest sites. Composite soil samples were colleted at $0-0.20 \mathrm{~m}$ of $10 \mathrm{sub}$-samples for each sampling site.

\section{Soil fertility analysis}

Soil $\mathrm{pH}_{(\mathrm{H} 2 \mathrm{O})}$, exchangeable cations $\left(\mathrm{Ca}^{2+}, \mathrm{Mg}^{2+}, \mathrm{K}^{+}\right.$, $\mathrm{Al}^{3+}$ ), and total soil $\mathrm{C}$ (Ctot), were measured according to Embrapa procedures (Embrapa, 1997). Based on these results, cation exchange capacity (CEC at $\mathrm{pH} 7$ ), sum of bases (SB) and base saturation (V) were calculated as soil fertility properties.

\section{Quantification of humic substances and total carbon}

The quantification of the three operationally defined humic substances (HS) fractions, fulvic acids (FA), humic acids (HA) and humin $(\mathrm{H})$ was done by the method described by Benites et al. (2003). The method is based on the extraction and separation of the alkali 


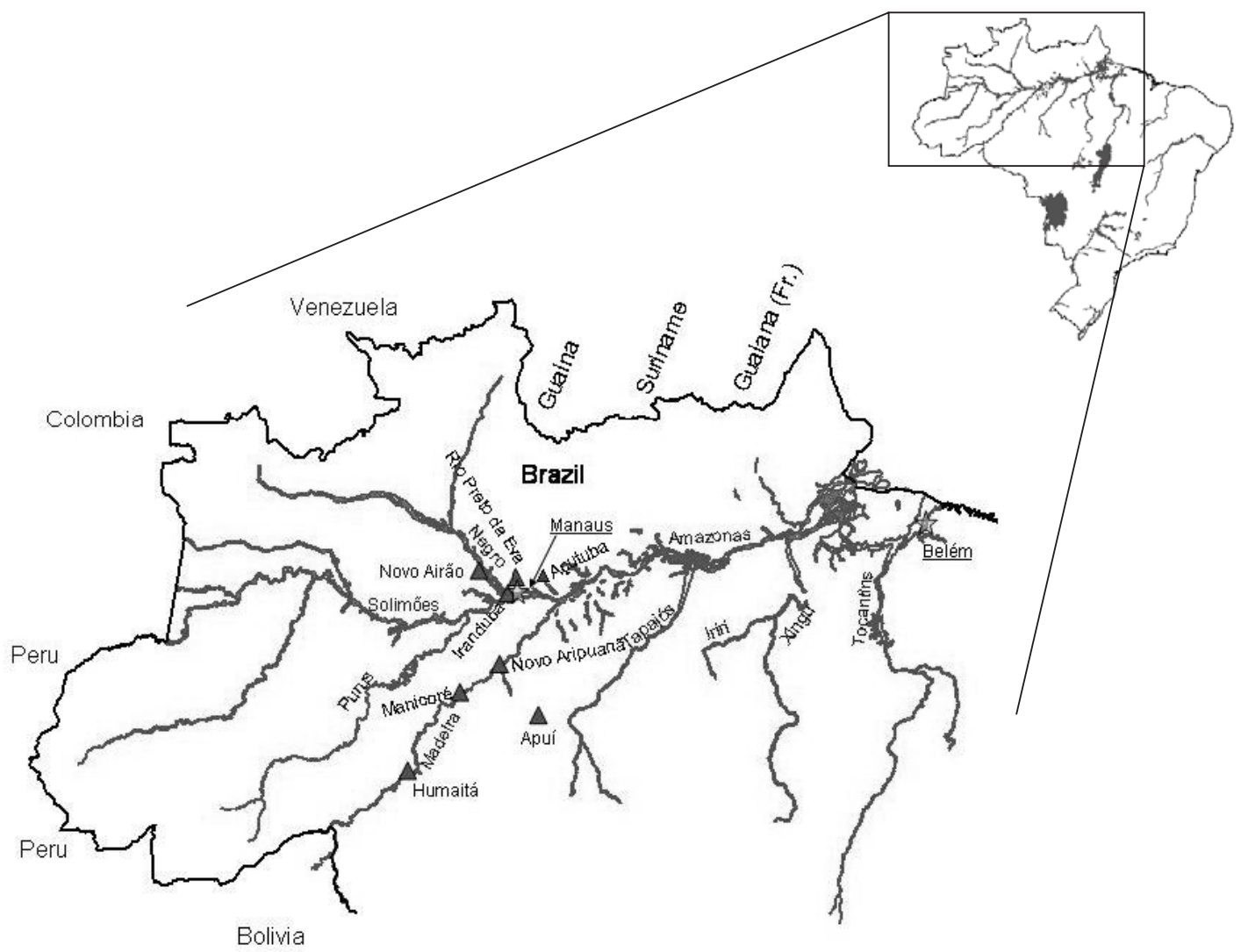

Figure 1. Localization of the areas where soil samples were collected. Triangles indicate administrative centers of municipalities.

Table 1. Sampling sites, corresponding soils, and their grouping for statistical analysis

\begin{tabular}{rllll}
\hline Sample & \multicolumn{1}{c}{ Soil } & Recent use & Acronym & Localization $^{(1)}$ \\
\hline 1 & Anthropogenic Soil & Forest & ASF & Humaitá \\
2 & Anthropogenic Soil & Forest & ASF & Novo Aripuanã \\
3 & Anthropogenic Soil & Forest & ASF & Apuí \\
4 & Anthropogenic Soil & Forest & ASF & Apuí \\
5 & Anthropogenic Soil & Forest & ASF & Iranduba \\
6 & Anthr opogenic Soil & Forest & ASF & Rio Preto da Eva \\
7 & Anthropogenic Soil & Cultivated & ASC & Humaitá \\
8 & Anthropogenic Soil & Cultivated & ASC & Novo Aripuanã \\
9 & Anthropogenic Soil & Cultivated & ASC & Apuí \\
10 & Anthropogenic Soil & Cultivated & ASC & Rio Preto da Eva \\
11 & Anthropogenic Soil & Cultivated & ASC & Rio Preto da Eva \\
12 & Anthropogenic Soil & Cultivated & ASC & Novo Airão \\
13 & Anthropogenic Soil & Cultivated & ASC & Rio Preto da Eva \\
14 & Anthropogenic Soil & Cultivated & ASC & Rio Preto da Eva \\
15 & Anthropogenic Soil & Cultivated & ASC & Iranduba \\
16 & Anthropogenic Soil & Cultivated & ASC & Iranduba \\
17 & Anthropogenic Soil & Cultivated & ASC & Novo Airão \\
18 & Anthropogenic Soil & Cultivated & ASC & Açutuba \\
19 & Non-Anthropogenic Soil & Forest & NAF & Manicoré \\
20 & Non-Anthropogenic Soil & Forest & NAF & Humaitá \\
21 & Non-Anthropogenic Soil & Forest & NAF & Manicoré \\
22 & Non-Anthropogenic Soil & Forest & NAF & Humaitá
\end{tabular}

(1) Localization indicates the centers of the municipalities where soil samples were collected, all of them in the State of Amazonas. ASF: Anthropogenic Soil under Forest, ASC: Anthropogenic Soil under Cultivation, NASF: Non-Anthropogenic Soil under Forest. 
soluble (HA and FA) from the insoluble fractions $(\mathrm{H})$ by aqueous solution of $0.1 \mathrm{~mol} \mathrm{~L}^{-1} \mathrm{NaOH}$, and separation of HA from FA using aqueous solution of $6 \mathrm{~mol} \mathrm{~L}^{-1} \mathrm{HCl}$. The determination of $\mathrm{C}$ in the $\mathrm{H}$ fraction was based on digestion by $0.167 \mathrm{~mol} \mathrm{~L}^{-1} \mathrm{~K}_{2} \mathrm{Cr}_{2} \mathrm{O}_{7}$ using tubes placed in heating blocks, and subsequent titration by $0.25 \mathrm{~mol} \mathrm{~L}^{-1} \mathrm{Fe}\left(\mathrm{NH}_{4}\right)_{2}\left(\mathrm{SO}_{4}\right)_{2} \cdot 6 \mathrm{H}_{2} \mathrm{O}$. The $\mathrm{C}$ in the $\mathrm{HA}$ and FA fractions was determined similarly, but using $0.042 \mathrm{~mol} \mathrm{~L}^{-1} \quad \mathrm{~K}_{2} \mathrm{Cr}_{2} \mathrm{O}_{7}$ and $0.0125 \mathrm{~mol} \mathrm{~L}^{-1} \mathrm{Fe}\left(\mathrm{NH}_{4}\right)_{2}\left(\mathrm{SO}_{4}\right)_{2} \cdot 6 \mathrm{H}_{2} \mathrm{O}$. The ratios of HA by FA (HA:FA) and the alkali soluble fractions $(\mathrm{FA}+\mathrm{HA}=\mathrm{EA})$ by $\mathrm{H}(\mathrm{EA} / \mathrm{H})$ were calculated to characterize the humified fraction of SOM (Benites et al., 2003).

Total $\mathrm{C}$ in the soil samples and humic fractions was measured by combustion at $925^{\circ} \mathrm{C}$ using a Perkin Elmer CHN/O Analyzer 2400 Series II (Perkin Elmer Life and Analytical Sciences, Inc. Boston, MA, EUA).

\section{Statistical analysis}

The sampling sites were separated in three groups before analysis: anthropogenic soils under forest (ASF, $\mathrm{n}=6$ ), anthropogenic soils under cultivation (ASC, $\mathrm{n}$ $=12$ ), and non-anthropogenic soils under forest (NASF, $\mathrm{n}=4$ ). Significant differences between soil groupings were determined using Tukey's Studentized Range (HSD) Test at $5 \%$. Bivariate correlation (Pearson's) was established between soil fertility properties and SOM fractions.

\section{RESULTS AND DISCUSSION}

\section{Fertility of anthropogenic dark earths}

A wide variation of values was detected in the anthropogenic soils, mainly for Ctot, S, V, and P (Table 2).
The difference between the total $\mathrm{C}$ content of the anthropogenic soils and NASF is very pronounced in humid tropical environment, where soils are highly weathered. The high $\mathrm{C}$ content in soils with anthropogenic A horizons were also observed by Sombroek (1966), Ranzani et al. (1970), Smith (1980), Éden et al. (1984), Kern \& Kämpf (1989), and Pabst (1991), and was attributed to organic matter stabilization by complex-formation with $\mathrm{Ca}^{2+}$, and enrichment in stable $\mathrm{C}$ structures (black $\mathrm{C}$ ). This fact is a possible explanation for the better fertility characteristics (Table 2) of the dark earths compared to non-anthropogenic soils. The high $\mathrm{C}$ content is a diagnostic attribute of anthropogenic soils of the Brazilian Amazon Basin, together with the presence of ceramic and lithic artifacts of former Indian civilization (Embrapa, 2006; Kämpf et al., 2003).

The anthropogenic soils (ASF and ASC) had higher $\mathrm{pH}$ and higher concentrations of basic cations (except $\mathrm{K}^{+}$) and available $\mathrm{P}$, and lower concentration of $\mathrm{Al}^{3+}$. Consequently, the SB, V, and CEC of the anthropogenic soils were also higher than in Ferralsols (NASF). There was no significant difference between cultivated anthropogenic soils (ASC) and those under forest (ASF), except for available P that was higher for ASC. Total soil C in anthropogenic was also significantly higher than in the corresponding surface layer of nonanthropogenic soils. The values found for soil fertility properties of anthropogenic soils are comparable to those reported by Smith (1980), Éden et al. (1984), Kern \& Kämpf (1989) and Lima et al. (2002) for other anthropogenic soil sites in the Brazilian Amazon.

The marked difference between fertility characteristics of the anthropogenic and nonanthropogenic soils can be attributed to the accumulation of organic matter, base cations, and other nutrients due to the addition of organic wastes (manure, vegetal and animal organic residues, bones) and black $\mathrm{C}$ provided by fire management by pre-

Table 2. Mean values of soil chemical properties and their variance within each soil group

\begin{tabular}{|c|c|c|c|c|c|c|c|c|c|c|}
\hline Group & pH in water & Ctot & $\mathrm{Ca}^{2+}$ & $\mathrm{Mg}^{2+}$ & $\mathbf{K}^{+}$ & $\mathrm{Al}^{3+}$ & SB & CEC at pH7 & $\mathbf{V}$ & $\mathbf{P}$ \\
\hline & & $\mathrm{g} \mathrm{kg}^{-1}$ & . & & - & \multicolumn{3}{|c|}{$\mathrm{cmol}_{\mathrm{c}} \mathrm{kg}^{-1}$} & $\%$ & $\mathrm{mg} \mathrm{kg}^{-1}$ \\
\hline ASF & $5.1 \mathrm{a}$ & $44.6 \mathrm{a}$ & $8.8 \mathrm{a}$ & $1.3 \mathrm{a}$ & $0.1 \mathrm{a}$ & $0.1 \mathrm{~b}$ & $10.3 \mathrm{a}$ & $17.5 \mathrm{a}$ & $59 \mathrm{a}$ & $116.0 \mathrm{~b}$ \\
\hline ASC & $5.5 \mathrm{a}$ & $44.7 \mathrm{a}$ & $7.4 \mathrm{a}$ & $1.3 \mathrm{a}$ & $0.1 \mathrm{a}$ & $0.1 \mathrm{~b}$ & $8.9 a$ & $17.2 \mathrm{a}$ & $50 \mathrm{a}$ & $290.5 \mathrm{a}$ \\
\hline NASF & $4.4 \mathrm{~b}$ & $37.9 \mathrm{~b}$ & $1.0 \mathrm{~b}$ & $0.7 \mathrm{~b}$ & $0.2 \mathrm{a}$ & $0.6 \mathrm{a}$ & $2.0 \mathrm{~b}$ & $9.5 \mathrm{~b}$ & $18 \mathrm{~b}$ & $4.7 \mathrm{c}$ \\
\hline \multicolumn{11}{|c|}{ Variance within the soil groups (\%) } \\
\hline ASF & 1.0 & 45.0 & 7.0 & 1.0 & 0.0 & 0.1 & 11.5 & 20.6 & 95 & 7597.8 \\
\hline ASC & 0.3 & 100.9 & 15.6 & 0.5 & 0.0 & 0.1 & 22.6 & 26.0 & 415 & 123954.7 \\
\hline NASF & 0.1 & 34.7 & 1.4 & 0.5 & 0.0 & 0.1 & 4.1 & 8.7 & 227 & 12.2 \\
\hline
\end{tabular}

Ctot: total soil carbon; SB: sum of bases; CEC: cation exchange capacity; V: base saturation; P: available phosphorus - Mehlich1 solution. The values indicated by different letters within a column are different at $p \leq 0.05$. ASF: anthropogenic soils under forest; ASC: anthropogenic soils under cultivation; NASF: non-anthropogenic soils under forest. 
Columbian civilization (Smith, 1980). No significant difference was observed in relation to $\mathrm{K}^{+}$content, probably because the organic complexes with $\mathrm{K}^{+}$are not stable and are easily removed by percolation. The higher levels of basic cations in anthropogenic soils (ASF and ASC) can explain higher $\mathrm{pH}$ values (Table 2) that have also been reported by Glaser et al. (2002) and Lehmann et al. (2003).

The higher CEC in soils with anthropogenic A horizons might be explained, besides the difference in $\mathrm{SOM}$ and basic cation and $\mathrm{Al}^{3+}$ levels, by the qualitative difference in SOM. In both anthropogenic and non-anthropogenic soils the predominant clay minerals are kaolinite and $\mathrm{Fe}$ and $\mathrm{Al}$ oxides with low charge density, since organic matter plays a fundamental role in soil reactions and accounts mainly for soil fertility (Sombroek, 1966). High quantities of black $\mathrm{C}$ were found in the anthropogenic soils (Glaser et al., 2000, 2001), up to $35 \%$ of soil organic matter compared to up to $14 \%$ in adjacent non-anthropogenic soils. This material makes the formation of stable organo-mineral complexes and nutrient retention in soil possible (Cunha et al., 2007), due to its compositional, structural and physico-chemical properties. The elevated $\mathrm{O} / \mathrm{C}$ and $\mathrm{O} / \mathrm{H}$ ratios of the humic acid fraction indicate high chemical reactivity, and the higher thermogravimetric index compared to non-anthropogenic humic acids indicates higher resistance to thermal degradation and corresponding molecular properties (aromatic polycyclic nuclei). These properties are responsible for a higher overall stability in the soil system.

The variability of values among the anthropogenic sites observed especially for Ctot, S, V, and P (Table 2) is most probably due to the circumstances of the formation of these soils, that is, the addition of different amounts of material (residues and carbonized material) of different composition and during different time ranges in the pre-Columbian era. Great variability in the distribution of soil chemical properties (Kern, 1988) and organic matter fractions (Beckman et al., 2005) was also observed within one single site of dark earths.

\section{Carbon distribution in humic substance fractions}

In all soil groups the major part of $\mathrm{C}$ in humic substances was found in the humin fraction $(\mathrm{H})$, corresponding to $43-49 \%$ of Ctot in surface horizons (Table 3). These results are in agreement with previous works on humic substances in tropical soils by Volkoff \& Cerri (1981), Volkoff \& Cerri (1988) and Martins (1987).

In common Ferralsols, during the humification process, organic residues at the soil surface are easily and quickly transformed (mineralization process) generating pre-humic products that can be removed to sub-surface horizons by water percolation. The major part of these products become FA and a minor part can be stabilized as HA and $\mathrm{H}$ fractions (Volkoff \& Andrade, 1976; Volkoff et al., 1978; Volkoff \& Cerri, 1988). In the soils with anthropogenic A horizon the predominant alkali soluble fraction was the HA fraction. In the non-anthropogenic soils the level of the FA fraction was approximately that of the HA, as it generally occurs in Ferralsols under humid tropical climate. This indicates that in the anthropogenic soils the humification process are possibly and soil C dynamics are definitely different. Lima et al. (2002) also found an enrichment of $\mathrm{HA}$ and $\mathrm{H}$ fractions in soils with anthropogenic A horizon located in the Brazilian Amazon. He found values of HA:FA ratio 14 for an Inceptisol and 4 for an Oxisol within the anthropogenic horizon. The average HA:FA ratio in anthropogenic dark earths found here was 2.8 (Table 3).

According to Zech et al. (1990), the predominance of the HA fraction, compared to FA in anthropogenic soils, contrary to observations in non-anthropogenic profiles of Ferralsols, may be the result of intense humification processes of organic residues rich in $\mathrm{N}$, $\mathrm{P}$ and $\mathrm{Ca}$ incorporated to the soil. The highest proportion of the more stable alkali fraction (HA) of humic substances is accompanied by higher levels of base cations (Table 3). This combination in anthropogenic soils indicates the presence of organic matter of higher quality in terms of soil fertility

Table 3. Mean levels of total soil carbon, humic substance fractions (FA, HA, H), and their ratios (HA:FA, EA/ $H)$ in the 0-20 cm soil layer. FA, HA, and $H$ is also expressed as percentage (\%) of total carbon

\begin{tabular}{|c|c|c|c|c|c|c|c|c|}
\hline Groups & FA & HA & $\mathbf{H}$ & FA & HA & $\mathbf{H}$ & HA:FA & EA/H \\
\hline & \multicolumn{3}{|c|}{$\mathrm{g} \mathrm{kg}^{-1}$} & \multicolumn{3}{|c|}{$\%$} & & \\
\hline $\mathrm{ASF}$ & $6.3 \mathrm{a}$ & $13.9 \mathrm{a}$ & $20.1 \mathrm{a}$ & $15 \mathrm{a}$ & $31 \mathrm{a}$ & $45 \mathrm{a}$ & $2.4 \mathrm{a}$ & $1.1 \mathrm{a}$ \\
\hline ASC & $5.1 \mathrm{a}$ & $14.6 \mathrm{a}$ & $19.3 \mathrm{a}$ & $11 \mathrm{a}$ & $33 a$ & $43 a$ & $3.2 \mathrm{a}$ & $1.1 \mathrm{a}$ \\
\hline NASF & $5.9 \mathrm{a}$ & $7.1 \mathrm{~b}$ & $18.6 \mathrm{a}$ & $16 \mathrm{a}$ & $19 b$ & $49 a$ & $1.4 \mathrm{~b}$ & $0.7 \mathrm{a}$ \\
\hline
\end{tabular}

FA: fulvic acid fraction, HA: humic acid fraction, H: humin fraction, EA: the alkali soluble fractions of humic substances (FA + HA

= EA). The values indicated by different letters within a column are different at $\mathrm{p} \leq 0.05$. ASF: anthropogenic soils under forest; ASC: anthropogenic soils under cultivation; NASF: non-anthropogenic soils under forest. 
potential. The changes in soil organic matter by higher HA content or enhanced HA:FA ratio in highly weathered soils contributed to enhance soil quality. The HA:FA ratio as index to evaluate humus quality was used by Kononova (1966). In the case of the Terra Preta soils, the improvement in the HA:FA ratio may be considered an indirect indicator by indicating conditions in the soil that favor humification processes such as the presence of polyvalent base cations that would lead to the build-up of larger humus molecules by complex formation. Better soil physical properties, such as better aggregation and a higher water infiltration rate, induced by higher SOM levels and the presence of $\mathrm{Ca}^{2+}$, may also contribute to the formation of larger molar masses through condensation processes (abiotic processes that occur mainly in drier environments).

\section{The humin fraction of SOM and soil fertility in the anthropogenic dark earths}

Correlation was observed between CEC and the HS fractions and the HA:FA ratio, however, not for all soil groups (Table 4). The correlation between Ctot and CEC for all soils (ASF+ASC+NASF) was medium $(r=0.72)$. There was a correlation, between CEC and $\mathrm{HA}$ and $\mathrm{H}$ fractions (0.56 and 0.65 , respectively), and there was no correlation between the FA fraction and the HA:FA and EA/H ratios. For the group of the anthropogenic soils (ASF+ASC) higher correlation (0.80) was found between Ctot and CEC than for all soils (ASF+ASC+NASF). For these soils no correlation was found between CEC and FA, HA, HA:FA and EA/ $\mathrm{H}$, only between CEC and $\mathrm{H}(0.81)$. In the group of non-anthropogenic soils (NASF) there was no correlation between $\mathrm{CEC}$ and Ctot, $\mathrm{HA}, \mathrm{H}$, and EA/ $\mathrm{H}$, however, correlations were observed between CEC and FA (0.97) and HA:FA (-0.94).

According to the results presented in table 4, the HA:FA ratio does not seem to be a relevant direct indicator of humus and soil quality for the anthropogenic soils. The reason for this might be that in the anthropogenic soils the formation of humic substances and their physico-chemical and compositional properties do not entirely depend on the processes of humification and the conditions of humification. Another factor that plays an important role in the formation is the carbonized material that is accumulated in great amounts in these soils. It was shown by Novotny et al. (2007) that the structural composition of the HA of the anthropogenic dark earths in the Amazon basin is very similar to that of black C. A similar conclusion was drawn by Zech et al. (1990) for H. Therefore, the structural composition of the HS of the anthropogenic soils was inherited from carbonized material, and this largely determines soil properties and function. Therefore, indicators that are valid for the evaluation of soil organic matter quality or soil fertility of non-anthropogenic soils in the humid tropics may not be relevant for the anthropogenic dark earths of the Amazon basin.

The correlation between the $\mathrm{CEC}$ and the $\mathrm{H}$ fraction also indicated that the $\mathrm{H}$ fraction has a very important contribution to the fertility potential of the anthropogenic soils. This is in contrast to the general view by which the $\mathrm{H}$ fraction would be the least reactive fraction of humic substances (Stevenson, 1994). In the case of anthropogenic soils, this fraction, apparently, contains not only the major part of $\mathrm{C}$ of humic substances, but also has a high chemical reactivity, which may have further contributed to the composition that was at least partly inherited from carbonized material.

The fact that CEC is strongly related to a stable fraction $(\mathrm{H})$ of SOM has important consequences for the sustainability of soil fertility in tropical ecosystems. In tropical regions the consequences of inappropriate soil management is rapidly manifested. One of the most important soil components that is severely affected by management systems is SOM. Inappropriate soil management promotes accelerated SOM oxidation and land degradation. The anthropogenic dark earths are therefore an important model for soil fertility management in regions under humid tropical climate. The existence of the Terra Preta model is evidence that sustainable agricultural activity is feasible in tropical areas, even under unfavorable conditions, such as inherently low fertility soils and high leaching rates.

Table 4. Correlation between cation exchange capacity (CEC pH 7,0) and the humic substances (HS) fractions (FA, HA, H)

\begin{tabular}{lcccccc}
\hline Soil groups (CEC) & Total C & FA & HA & H & HA:FA & EA/H \\
\hline ASF+ASC+NASF & $0.72^{* * *}$ & $\mathrm{~ns}$ & $0.56^{* *}$ & $0.65^{* *}$ & $\mathrm{~ns}$ & $\mathrm{~ns}$ \\
ASF+ASC & $0.80^{* * *}$ & $\mathrm{~ns}$ & $\mathrm{~ns}$ & $0.81^{* * *}$ & $\mathrm{~ns}$ & $\mathrm{~ns}$ \\
NASF & $\mathrm{ns}$ & $0.96^{*}$ & $\mathrm{~ns}$ & $\mathrm{~ns}$ & -0.94 & $\mathrm{~ns}$ \\
\hline
\end{tabular}

ASF: anthropogenic soil under forest, ASC: anthropogenic soil under cultivation, NAS: non-anthropogenic soil, FA: fulvic acid, HA: humic acid, H: humin, EA: the alkali soluble fractions of humic substances (FA + HA = EA). ${ }^{*} p<0.05,{ }^{* *} p<0.01,{ }^{* * *} p<0.001$, without asterix: $p<0.06$, ns: not significant. ASF: anthropogenic soils under forest; ASC: anthropogenic soils under cultivation; NASF: non-anthropogenic soils under forest. 


\section{CONCLUSIONS}

1. The distribution of $\mathrm{C}$ among humified fractions shows that humin $(\mathrm{H})$ is the predominant fraction, as generally true for Ferralsols, but in the soils with anthropogenic A horizon an accumulation of the humic acid (HA) fraction relative to the fulvic acid (FA) fraction was observed which is unusual for Feralsols in humid tropical climate.

2. In anthropogenic soils CEC in the $0-20 \mathrm{~cm}$ soil layer was highly related to humin levels, a more stable SOM fraction, and total C. The anthropogenic dark earths of the Amazon basin may therefore represent an important model for the study of alternative soil management practices for sustainable soil fertility management in the humid tropics.

\section{ACKNOWLEDGEMENTS}

The authors are grateful for the financial support by Embrapa.

\section{LITERATURE CITED}

BECKMAN, E.H.; SOUZA, L.F.; COELHO, M.R.; MARTINS, G.C. \& MADARI, B.E. Distribuição vertical e horizontal de substâncias húmicas em terra preta de índio, município Rio Preto da Éva, Amazonas. In: CONGRESSO BRASILEIRO DE CIÊNCIA DO SOLO, 30., Recife, 2005. Anais. Recife, 2005. CD-ROM.

BENITES, V.M.; MADARI, B. \& MACHADO, P.L.O.A. Extração e fracionamento quantitativo de substâncias húmicas do solo: Um procedimento simplificado de baixo custo. Rio de janeiro, Embrapa Solos, 2003. 7p. (Comunicado Técnico, 16).

CANELLAS, L.P.; VELLOSO, A.C.X.; MARCIANO, C.R.; RAMALHO, J.F.G.P.; RUMJANEK, V.M.; REZENDE, C.E. \& SANTOS, G.A. Propriedades químicas de um Cambissolo cultivado com cana-de-açúcar, com preservação do palhiço e adição de vinhaça por longo tempo. R. Bras. Ci. Solo, 27:935-944, 2003.

CANELLAS, L.P.; VELLOSO, A.C.X.; RUNJANEK, V.M.; GURIDI, F.; OLIVARES, F.L.; SANTOS, G.A. \& BRAZFILHO, R. distribution of the humified fractions and characteristics of the humic acids of an Ultisol under cultivation of eucalyptus and sugar cane. Terra Latinoamericana, 20:371-381, 2002.

CUNHA, T.J.F.; MADARI, B.E.; BENITES, V.M.; CANELLAS, L.P.; NOVOTNY, E.H.; MOUTTA, R.O.; TROMPOWSKY, P.M. \& SANTOS, G.A. Fracionamento químico da matéria orgânica e características de ácidos húmicos de solos com horizonte A antrópico da Amazônia (Terra Preta). Acta Amaz., 37:91-98, 2007.
CUNHA, T.J.F. Ácidos húmicos de solos escuros da Amazônia: Terra Preta de Indio. Rio de Janeiro, Universidade Federal do Rio de Janeiro, 2005. 140p. (Tese de Doutorado)

ÉDEN, M.J.; BRAY, W.; HERRERA, L. \& MCEWAN, C. Terra Preta Soils and their archaelogical context in the Caquetá Basin of Southeast Colombia. Am. Antiquity, 49:125-140, 1984.

EMPRESA BRASILEIRA DE PESQUISA AGROPECUÁRIA EMBRAPA. Sistema brasileiro de classificação de solos. 2.ed. Rio de Janeiro, Embrapa Solos, 2006. 306p.

EMPRESA BRASILEIRA DE PESQUISA AGROPECUÁRIA EMBRAPA. Manual de métodos de análise de solo. 2.ed. Rio de Janeiro, 1997. 212p. (Embrapa Solos Documentos, 1)

FAO. World Reference Base for Soil Resources. Rome, FAO, ISRIC, ISSS, 1994. 88p. (World Soil Resources Report, 84)

FONTES, M.P.F.; CAMARGO, O.A. \& SPOSITO, G. Eletroquímica das partículas coloidais e sua relação com a mineralogia de solos altamente intemperizados. Sci. Agric., 58:627-646, 2001.

GLASER, B.; BALASHOV, E.; HAUMAIER, L.; GUGGENBERGER, G. \& ZECH, W. Black carbon in density fractions of anthropogenic soils of the Brazilian Amazon region. Organic Geochem., 31:669-678, 2000.

GLASER, B.; HAUMAIER, L.; GUGGENBERGER, G. \& ZECH, W. The "Terra Preta" phenomenon: A model for sustainable agriculture in the humid tropics. Naturwissenschaften, 88:37-41, 2001.

GLASER, B.; LEHMANN, J. \& ZECH, W. Ameliorating physical and chemical properties of highly weathered soil in the tropics with charcoal: A review. Biol. Fert. Soils, 35:219-230, 2002

HARGITAI, L. The role of organic matter content and humus quality in the maintenance of soil fertility and in environmental protection. Landscape Urban Plan., 27:161-167, 1993.

KÄMPF, N.; WOODS, W.I.; SOMBROEK, W.; KERN, D.C. \& CUNHA, T.J.F. Classification of Amazonian Dark Earths in the Brazilian Amazon. In: LEHMANN, J.; KERN, D.C.; GLASER, B. \& WOODS, W.I. Amazonian Dark Earths: Origin, properties, management. Dordrecht, Kluwer, 2003. p.77-102.

KERN, D.C. Caracterização pedológica de solos com Terra Preta Arqueológica na Região de Oriximiná, Pará. Porto Alegre, Universidade Federal do Rio Grande do Sul, 1988. 231p. (Tese de Mestrado)

KERN, D.C. \& KÄMPF, N. Antigos assentamentos indígenas na formação de solos com terra preta arqueológica na região de Oriximiná-Pará. R. Bras. Ci. Solo, 13:219-225, 1989

KONONOVA, M.M. Soil organic matter: Its nature, its role in soil formation and in soil fertility. Oxford, Pergamon Press, 1966. p.127-166. 
LEHMANN, J.; DA SILVA JR.; STEINER, C.; NEHLS, T.; ZECH, W. \& GLASER, B. Nutrient availability and leaching in an archaeological Anthrosol and a Ferralsol of the Central Amazon basin: Fertilizer, manure and charcoal amendments. Plant Soil, 249:343-357, 2003.

LIMA, H.N.; SCHAEFER, C.E.R.; MELLO, J.W.V.; GILKES, R.J. \& KER, J.C. Pedogenesis and pre-Colombian land use of "Terra Preta Anthrosols" ("Indian black earth") of Western Amazonia. Geoderma, 110:1-17, 2002.

MARTINS, P.F.S. Conseqüências do desmatamento sobre o solo de um ecossistema de terra firme da Amazônia Oriental. Piracicaba, Escola Superior de Agricultura Luiz de Queiroz, 1987. 231p. (Tese de Doutorado)

MIELNICZUK, J.; BAYER, C.; VEZZANI, F.M.; LOVATO, T.; FERNANDES, F.F. \& DEBARBA, L. Manejo de solo e culturas e sua relação com os estoques de carbono e nitrogênio do solo. In: CURI, N.; MARQUES, J.J.; GUILHERME, L.R.G.; LIMA, J.M.; LOPES, A.S. \& ALVAREZ V., V.H. Tópicos em ciência do solo. Viçosa, MG, Sociedade Brasileira de Ciência do Solo, 2003. v.3. p.209-248.

NOVOTNY, E.H.; AZEVEDO, E.R.; BONAGAMBA, T.J.; CUNHA, T.J.F.; MADARI, B.E.; BENITES, V.M. \& HAYES, M.H.B. Studies of the compositions of humic acids from Amazonian Dark Earth Soils. Environ. Sci. Technol., 41:400-405, 2007.

ORLOV, R. Humic acids of soils. Washington, USDA/NSF 1985. 378 p.

PABST, E. Critérios de distinção entre Terra Preta e Latossolos na região de Belterra e os seus significados para a discussão pedogenética. B. Museu Paraense Emilio Goeldi, Série Antrop., 7:5-19, 1991.

PEIXOTO, R.T.G. Matéria orgânica e a dinâmica das cargas elétricas dos solos: Processos e conseqüências. In: CONGRESSO BRASILEIRO DE CIÊNCIA DO SOLO, 26., Rio de janeiro, 1997. Anais. Rio de janeiro, Embrapa CNPS, 1997. CD-ROM.

RANZANI, G.; KINJO, T. \& FREIRE, O. Ocorrências de "Plaggen Epipedon" no Brasil. Notícia Geomorf., 10:5562, 1970.

SMITH, N.J.H. Anthrosols and human carrying capacity in Amazonia. Ann. Assoc. Am. Geogr., 70:553-566, 1980.

SOARES, M.R.; ALLEONI, L.R.F.; VIDAL-TORRADO, P. \& COOPER, M. Mineralogy and ion exchange properties of the particle size fractions of some Brazilian soils in tropical humid areas. Geoderma, 125:355-367, 2005.
SOMBROEK, W.G. Amazon soils. A reconnaissance of the soils of the Brazilian Amazon region. Wageningen, Centre for Agricultural Publication and Documentation, 1966. 292p. (Agricultural Research Reports, 672)

SOUZA, W.J.O. \& MELO, W.J. Matéria orgânica em um Latossolo submetido a diferentes sistemas de produção de milho. R. Bras. Ci. Solo, 27:1113-1122, 2003.

SPOSITO, G. The chemistry of soils. New York, Oxford University Press, 1989. 277p.

STEVENSON, F.J. Humus chemistry: Genesis, composition, reactions. 2.ed. New York, John Willey, 1994. 496p.

VAUGHAN, D. \& MALCOLM, R.E. Soil organic matter and biological activity. Dordrecht, Kluwer, 1985. 356p.

VILLELA, D.M. \& PROCTOR, J. Litterfall mass, chemistry and nutrient retranslocation in a monodominant forest on Maracá Island, Roraima, Brazil. Biotropica, 31:198211, 1999

VOLKOFF, B.; FLEXOR, J.M.; SANTA-ISABEL, L.M. \& SANTA-ISABEL, M. Natureza do húmus nos Latossolos distróficos da Bahia. R. Bras. Ci. Solo, 2:59-63, 1978.

VOLKOFF, B. \& CERRI, C.C. L'humus des sols du Brésil: Nature et relation avec l'environnement. Cahiers ORSTOM, Série Pédologie, 24:83-95, 1988.

VOLKOFF, B. \& ANDRADE, M.J. Caracterização da matéria orgânica de alguns solos ferralíticos do Estado da Bahia: Aplicação de um método de fracionamento das substâncias húmicas. In: CONGRESSO BRASILEIRO DE CIÊNCIA DO SOLO, 15., Campinas, 1976. Anais. Campinas, 1976. p.116-126.

VOLKOFF, B. \& CERRI, C.C. Húmus em solos da floresta amazônica na região do rio Madeira. R. Bras. Ci. Solo, 5:15-21, 1981.

WOODS, W.I. \& MCCANN, J.M. El origen y persistencia de las tierras negras de la Amazonía. In: HIRAOKA, M. \& MORA, S. Desarrollo sostenible en la Amazonía. Mito o realidad? Quito, Ediciones Abya-Yala, 2001. p.23-30.

YAGI, R.; FERREIRA, M.E.; CRUZ, M.C.P. \& BARBOSA, J.C. Organic matter fractions and soil fertility under the influence of liming, vermicompost and cattle manure. Sci. Agric., 60:549-557, 2003.

ZECH, W.; HAUMAIER, L. \& HEMPFLING, R. Ecological aspects of soil organic matter in tropical land use. In: MCCARTHY, P.; CLAPP, C.E.; MALCOLM, R.L. \& BLOOM, P.R. Humic substances in soil and crop sciences: Selected readings. Madison, ASA, SSSA, 1990. p.187-201. 